\title{
The ROLE OF HUNTING IN VILLAGE LIVELIHOOdS IN THE ASHANTI REGION, GHANA
}

\author{
Douglas Crookes and David Humphreys \\ Centre for Environmental Policy, Imperial College London \\ Fransisca Masroh and Barbara Tarchie \\ Kwame Nkrumah University of Science and Technology, Ghana \\ EJ Milner-Gulland \\ Division of Biology, Imperial College London
}

\begin{abstract}
The article describes the results of two surveys conducted in six villages in the Ashanti region of Ghana. The first was undertaken in August 2002 and the second during July 2004. A total of 468 hunters and non-hunters were surveyed using targeted and systematic interviewing techniques. The results indicate that hunting is an important contributor to total income in the villages, particularly for poorer households. We find some evidence that hunting increases during lean periods, especially for hunters in the household survey. Distance to Kumasi is a significant determinant of the number of animals sold on the market, and also influences the type of gear used for hunting. Compliance with wildlife laws, notably species restrictions and the closed season is low, particularly amongst professional hunters.
\end{abstract}

Abstract

JEL Q12, Q21, Q57

\section{1 \\ Introduction}

Today, populations of all species of mediumlarge mammals are depleted in West Africa (Ntiamoa-Baidu, 1987) and in some cases have been eliminated from the markets (Cowlishaw et al., 2005). Two main processes are responsible for this - habitat conversion and hunting. Ghana's population increased thirteen fold between 1900 and 2000. In contrast, the high forest area decreased eight fold over the same period, from 8.2 million hectares at the turn of the century to one million by the mid 1990s (Wuver \& Attuquayefio, 2006). In an evaluation of the Subri forestry project, Korang (1986, cited in Asibey \& Child, 1990) found that 94 per cent of those surveyed considered the worst impact of forest conversion to be the loss of bushmeat in the area.

The consequences of the decline in bushmeat species are felt in at least three areas: firstly, it would appear that only the wealthy can afford to consume higher quantities of bushmeat (Wilkie et al., 2005; Owusu et al., 2006). Secondly, there is some evidence of consumers switching to other proteins in some areas. Fish in particular seems to be widely consumed as a protein substitute for bushmeat in Ghana (LWAG, 2002; Bowen-Jones, 2003; Brashares et al., 2004). A third consequence of depletion is that market participants travel greater distances to supply markets. For example, Milner-Gulland and Clayton (2002) found that traders were willing to travel significantly further to obtain bushmeat for markets in Sulawesi. All these consequences affect livelihoods directly or indirectly. For example, patterns of urban consumption and income affect demand, which in turn impact hunters through the price mechanism.

In order to understand the drivers of hunting behaviour, it is important to consider the impacts of hunting on the village economy, and vice versa. For example, since farming is 
an important source of income for hunting households in the Ashanti region (Damania et al., 2005), often these two activities are inextricably linked and the motivations for hunting may be found in crop protection or food security concerns. Furthermore, hunting can be an important source of revenue for rural households (Asibey, 1977). While there have been few empirical studies in Ghana, Wilkie and Carpenter (1999) found in reviewing the literature for the Congo basin that hunters can earn between $\$ 300$ and $\$ 700$ per annum from bushmeat sales.

This article describes the results of two surveys in six villages in the Ashanti region of Ghana that attempts to explore some of these issues. The first survey was conducted in August 2002 and the second in July 2004. The layout of the article is as follows: first, the role of hunting for the Ashanti people is assessed in terms of the contribution it makes to income, both on a hunter level and on a regional level. Hunter behaviour is then considered with reference to the effect of the village's distance from Kumasi as well as compliance with wildlife regulations.

\section{2}

\section{Methods}

\subsection{Study area}

The study villages all fall within the Ashanti region of Ghana (Figure 1), and form part of the Upper Guinea Forest Ecosystem, a biodiversity hotspot. The landscape is largely characterised by a patchwork mosaic (Caspary, 1999) with interspersed forest and agricultural land. Much of the forest in the Ashanti region is situated in an arc around Kumasi, the regional capital. There are a number of wildlife laws applicable to the management of natural resources such as bushmeat, including protected areas, species restrictions and a closed season when the hunting of most species is prohibited. A variety of crops are grown in the study area, including cassava, cocoa, and cocoyam.

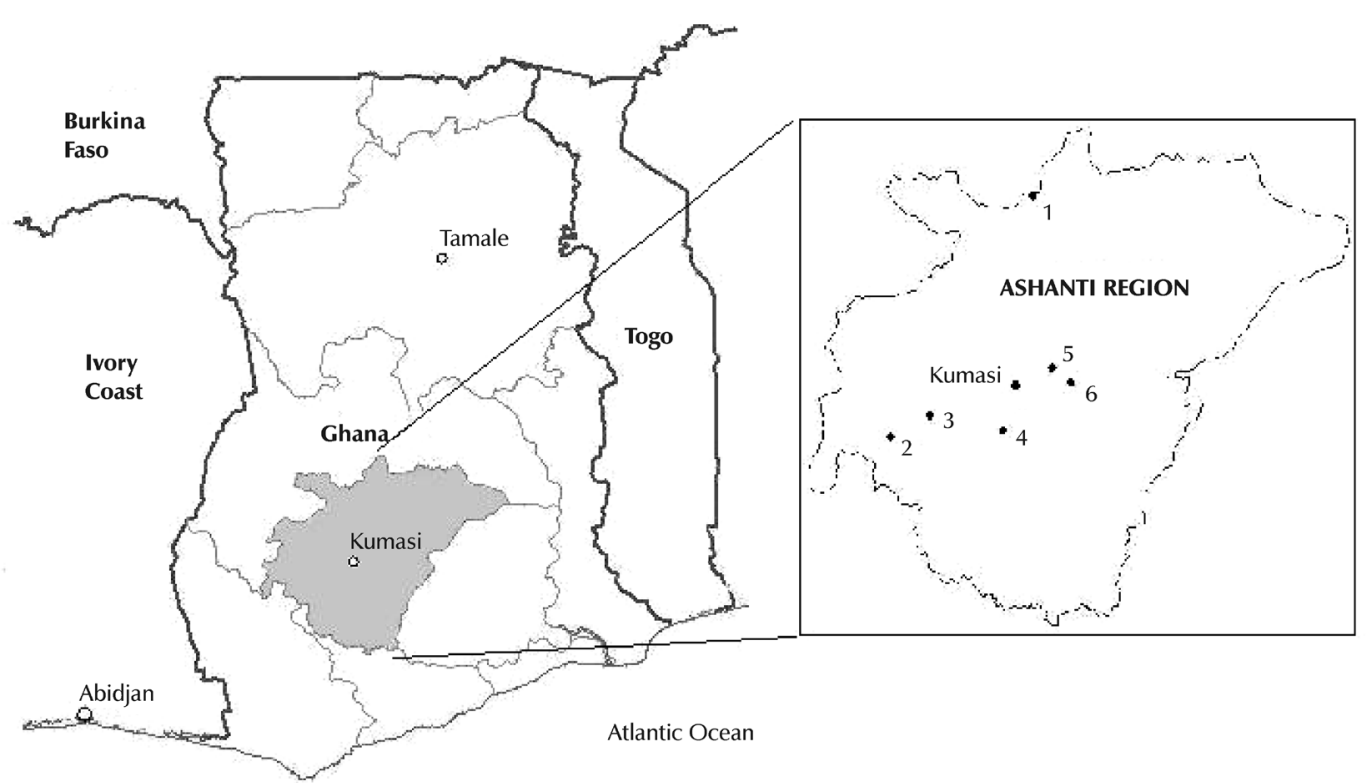

Figure 1

Map showing the location of the study sites. $1=$ Drobon; $2=$ Nagode; $3=$ Pakyi (Nkromma); $4=$ Pekyi No. $1 ; 5=$ Asotwe; $6=$ Atia 


\subsection{Village characteristics}

The villages represent a range of hunting conditions in Ashanti. All the villages have direct and/or indirect links with the bushmeat trade in Kumasi. The first of the villages surveyed, Pekyi No.1, is situated to the south of Kumasi, in an area comprising moderately dense bush (Table $1)$. The village is located quite near a major transportation route, approximately $20 \mathrm{kms}$ from the Kumasi metropolis and is a primary market for the supply of bushmeat. Pakyi, (known as Nkromma by the locals) and Nagode, the second and third villages surveyed, are situated west of Pekyi No.1, $40 \mathrm{kms}$ and $60 \mathrm{kms}$ respectively from Kumasi, and access to Kumasi is difficult. They are in the forest zone, located close to forest reserves. A number of the villagers are employed in forestry related activities such as timber felling. Drobon, in the far north of the Ashanti region, is relatively distant from Kumasi. It is, however, situated $5 \mathrm{kms}$ from the 10,000 person town of Sekyedumase. Asotwe and Atia are situated close to Kumasi, and Asotwe is affected by urban sprawl.

Table 1

Village location and characteristics ( $1=$ August $2002 ; 2=$ July 2004)

\begin{tabular}{|l|c|c|c|c|c|}
\hline Village & $\begin{array}{c}\text { Survey } \\
\text { date }\end{array}$ & Latitude & Longitude & Landcover ${ }^{2}$ & $\begin{array}{c}\text { Distance from } \\
\text { Kumasi }\end{array}$ \\
\hline Pekyi No.1 & 1 & $6^{\circ} 32^{\prime} 00 \mathrm{~N}$ & $1^{\circ} 41^{\prime} 00 \mathrm{~W}$ & Mod. Dense bush & $20 \mathrm{kms}(\mathrm{S})$ \\
\hline Pakyi (Nkromma) & 1 & $6^{\circ} 35^{\prime} 00 \mathrm{~N}$ & $1^{\mathrm{o}} 58^{\prime} 00 \mathrm{~W}$ & Mod. closed tree & $40 \mathrm{kms}(\mathrm{SW})$ \\
\hline Nagode & 1 & $6^{\circ} 31^{\prime} 00 \mathrm{~N}$ & $2^{\circ} 08^{\prime} 00 \mathrm{~W}$ & Closed forest & $60 \mathrm{kms}(\mathrm{SW})$ \\
\hline Asotwe & 2 & $6^{\circ} 45^{\prime} 00 \mathrm{~N}$ & $1^{\circ} 27^{\prime} 00 \mathrm{~W}$ & Mod. Dense bush & $10 \mathrm{kms}(\mathrm{E})$ \\
\hline Atia & 2 & $6^{\circ} 42^{\prime} 00 \mathrm{~N}$ & $1^{\circ} 24^{\prime} 00 \mathrm{~W}$ & Mod. Dense bush & $20 \mathrm{kms}(\mathrm{E})$ \\
\hline Drobon & 2 & $7^{\circ} 23^{\prime} 00 \mathrm{~N}$ & $1^{\circ} 34^{\prime} 00 \mathrm{~W}$ & Mod. Dense bush & $75 \mathrm{kms}(\mathrm{N})$ \\
\hline
\end{tabular}

${ }^{1}$ As defined in the Ghana Living Standards Survey (GLSS, 1998/9) (Ghana Statistical Service, 2000)

${ }^{2}$ Based on a GIS coverage map for the Ashanti region supplied by the Forestry Commission, Ghana

\subsection{Survey methodology}

As indicated in the introduction two surveys were administered, one in 2002 and the other in 2004, to hunter and non-hunter households. In the 2002 survey a total of 80 households were interviewed in the villages of Pekyi No.1 and Nagode using systematic sampling techniques. The questionnaire asked a series of questions related to the livelihood activities of households, and also contained a hunter section for those households that had a resident hunter. The sampling interval was chosen to ensure that the full geographical area of the village was covered by the survey. A further five household interviews were carried out in Pakyi (Nkromma), targeted to hunter households in order to boost the number of hunters in the first survey. Hunter households were identified by asking villagers for the location of these households and a hunter in that household was then surveyed.

In the 2004 survey two questionnaires were administered. In the first, 303 hunter and nonhunter households were interviewed with regard to their livelihood activities. Interviews were conducted on the day of the week when people were in the village rather than farming. In the second questionnaire a further 80 interviews were conducted targeting hunters specifically - in Asotwe, Atia and Drobon - hereafter known as the "hunter" survey. Percentage of households surveyed ranged from four per cent in Pakyi (Nkromma) through to 32 per cent in Atia (Table 2).

Two enumerators were used in the 2002 survey, and ten in the 2004 survey. The total sample from the two surveys was 468 . 


\section{Table 2}

Sample characteristics of the surveyed villages. Most household sizes averaged between 4 and 8 persons. An exception was Pekyi No.1 where the household sizes averaged almost 14 .

\begin{tabular}{|c|c|c|c|c|c|}
\hline \multirow[b]{2}{*}{ Village } & \multicolumn{2}{|c|}{ Number surveyed } & \multirow[b]{2}{*}{$\begin{array}{l}\text { No. of hhs in } \\
\text { village }\end{array}$} & \multirow[b]{2}{*}{$\begin{array}{c}\text { Total } \\
\text { population }\end{array}$} & \multirow{2}{*}{$\begin{array}{c}\text { Percentage } \\
\text { of hhs } \\
\text { surveyed }\end{array}$} \\
\hline & $\begin{array}{l}\text { Hunter } \\
\text { survey }\end{array}$ & $\begin{array}{l}\text { Household } \\
\text { survey }\end{array}$ & & & \\
\hline Asotwe & 20 & 120 & 685 & 2,923 & 18 \\
\hline Atia & 35 & 106 & 334 & 1,629 & 32 \\
\hline Drobon & 25 & 77 & 261 & 1,335 & 30 \\
\hline Nagode & - & 45 & 149 & 1,151 & 30 \\
\hline Pakyi (Nkromma) & - & 5 & 135 & 1,050 & 4 \\
\hline Pekyi No.1 & - & 35 & 242 & 3,289 & 15 \\
\hline Total & 80 & 388 & 1,806 & 11,377 & 21.5 \\
\hline
\end{tabular}

Population estimates for the villages were from the traditional authorities or local council representatives. Most of these estimates were probably obtained from census data or from the village's own records (updated if people arrive or depart), and are therefore expected to be fairly current. For Nagode, only estimates for the total number of adults were available. To obtain total population estimates for the village, we use the ratio of the total population in Ashanti region to the adult population. This was derived from published 2000 census information (Ghana Statistical Service, 2002).

We obtained two independent estimates of the proportion of hunters in the population. The first, from our household surveys, gave a proportion of approximately four per cent, and the second, from village chiefs in the first survey gave a proportion of 3.6 per cent. These results are consistent with estimates from other studies. The study by Hofmann et al., (1999) of three villages in the Ashanti region estimates that hunters comprise 3.4 per cent of the total population. This estimate was also based on information provided by village heads. NtiamoaBaidu (1998) conducted a survey of 124 hunters in five regions (Ashanti, Brong Ahafo, Central, Upper West and Volta) and estimated that parttime and full-time hunters comprise 5.6 per cent of the sample population of adult males between the ages of 15 and 80 . However, these figures hide the fact that quite a large proportion of households have at least one hunter (see Figure 2 for survey one).

\subsection{Regression models}

For the first set of regressions, the response variable is counts of number of animals sold by a hunter in a particular location in a year, either in the village or Kumasi. Covariates investigated included distance to Kumasi, hunting methods used, and number of animals consumed at home, given away, or sold in a different location. Since the data are characterised by overdispersion, a negative binomial model is fitted.

We test the hypothesis that hunting behaviour is seasonal, increasing during periods when agricultural activity diminishes, and decreasing during peak agricultural periods, rather than being influenced by the timing of the legal closed season for hunting. Using logistic regression, we regress months in which hunters reported hunting more or less against frequency counts for months when key staple crops grown in the study areas are harvested, derived from the Ghana Living Standards survey (Ghana Statistical Service, 2000) and a dichotomous variable to model the effect of the closed season (which spans from 1 August to 1 December).

We ran the regression models adjusting for the different sampling methodologies (systematic, 
targeted) using the survey routine in Stata/SE 9.2 (StataCorp, 2005). In both classes of models the primary sampling unit (PSU) was set at the hunter level. In the case of the crop data, this was to account for intra-class correlation. For the sales data, a constant dispersion is assumed rather than dispersion about the mean. Sample design effects ${ }^{1}$ (deft) are given in parenthesis after each point estimate (Kish, 1982, 1995).

\subsection{Estimating the contribution of hunting}

There are two methods for measuring gross income from hunting: "top-down" and "bottom up" approaches. Top-down approaches ask households to report the total annual income from hunting. This requires hunters to make estimates of annual earnings based on recollection, and may be appropriate for certain activities (eg. salaried employment) but less appropriate for others. Bottom-up approaches with respect to hunting would ask questions related to frequency of hunting, how many sold and whether there are periods when hunters hunt more or less, and also average price obtained for each animal. The total aggregate value of hunting income is then computed using this information. Although cognisance is taken of seasonal variation in hunting patterns, this adjustment is still only an approximation compared with actual hunting behaviour. The current study employs a "bottom-up" approach to estimating the contribution of hunting. This is also the method adopted by Tutu et al., (1993) and Ntiamoa-Baidu (1998).

The average cost of hunting is assumed constant and at the same ratio to revenue for all the studies. We use a ratio of 26 percent of revenue for the Ashanti region from NtiamoaBaidu's (1998) study. An estimate of the total number of hunters is derived based on the proportion of hunters in the same study and the total population for a given year. Multiplying the total number of hunters by the gross income per hunter gives an estimate of the total value of hunting in the Ashanti region. Gross domestic product (GDP) comprises compensation of employees, plus taxes less subsidies on production and imports, plus gross mixed income, plus gross operating surplus (OECD, 2000). Published data on GDP for the Ashanti region is not available (Ghana Statistical service, personal communication). In the absence of this data we use the ratio of Ashanti income to total income derived from the GLSS $91 / 2$ and GLSS 98/9 as a proxy for the ratio of Ashanti GDP to total GDP. This ratio has remained constant at approximately 20 per cent for those dates. Multiplying by the total GDP gives an estimate for Ashanti GDP.

\subsection{Correspondence analysis}

Correspondence analysis was used to look at the relationship between hunting method and village (Hill, 1974; Greenacre, 1984). Both row and column co-ordinates were scaled by their singular values (Greenacre, 2006). This enables the study of the interrelationship between row and column points.

\section{3}

\section{Results}

\subsection{Hunter characteristics}

The majority of hunters in the villages are older than the average age in the sample population. The mean age of hunters was 42.4 years $(\mathrm{SD}=$ \pm 11.4 ), which was higher than the mean age of 34 years reported by Tutu et al., (1993) in their study of hunters supplying the Kumasi market, although not significantly so. The absence of young hunters ( $<25$ years) is somewhat surprising, although Tutu et al. (1993) also found a similar sample age range (23-70 years). Our results for the younger adult (21-40 years) age category compare well with hunter age profiles elsewhere. 45.2 per cent of hunters in the sample fall within this age category, compared with 52 percent in study sites in Cote d'Ivoire (Caspary, 1999). In contrast, the number of years that a household has been involved with hunting is generally low. The majority of hunters (39 percent) have been hunting for between 5 and 10 years, and 26 percent less than 5 years. Hunters spend on average 5.83 hours hunting per trip $(\mathrm{SD}= \pm 3.8$, Tutu $=4.42$ hours $)$, with the average number of hunting trips per week 
equalling $2.54(\mathrm{SD}= \pm 2.0$, Tutu $=2.08)$. The mean distance travelled per trip is $5.6 \mathrm{~km}$ (SD $= \pm 3.3$, Tutu $=$ na).

The hunters targeted in the hunter survey reportedly started hunting for a variety of reasons: for the enjoyment of it (4 per cent), crop protection (33 per cent), as a source of income (39 per cent), and for food (10 per cent). Other reasons cited comprise 14 per cent. The distribution of whether hunters hunt at day or night is fairly even: 34 per cent hunt at night, 42 per cent hunt during the day and 24 per cent hunt day and night. An equal proportion of hunters also currently pursue hunting as a source of income (38 per cent) or food (32 per cent). About 30 per cent hunt to protect their crops. In the hunter survey, 34 per cent of catch is consumed at home, two per cent given away and the rest (44 per cent) is sold. Of that which is sold, 35 per cent goes to local traders, 30 per cent goes to traders at the Atwemonom market in Kumasi, and the rest goes to individuals, either in the village (22 per cent) or in Kumasi (13 per cent).

\subsection{Patterns of income and expenditure}

\subsubsection{Sources of income}

There are a total of fifteen income generating activities that the inhabitants of Pekyi No.1 and Nagode are involved with (Figure 2). The most lucrative of these is running a local store $\left(\right.$ mean $=\propto 13.0$ million $^{2}$ per annum); however hairdressing (mean $=\$ 5.2$ million), masonry $($ mean $=\$ 3.8$ million), shoemaking (mean $=$ $ф 3.6$ million) and timber felling (mean $=\notin 3.6$ million) are also fairly well-paid. Given the high start-up costs, it is not surprising that relatively few of the households are reportedly involved in these higher earning professions. The majority (91 per cent) of the households are involved in farming. This was followed by trading (35 per cent of hhs). The remaining activities with the exception of hunting were pursued by less than ten percent of households. Other activities more likely to be pursued by households include masonry (nine per cent), and dressmaking, driving and hairdressing (five per cent each). Hunting comprised 35 per cent of total income in these villages.

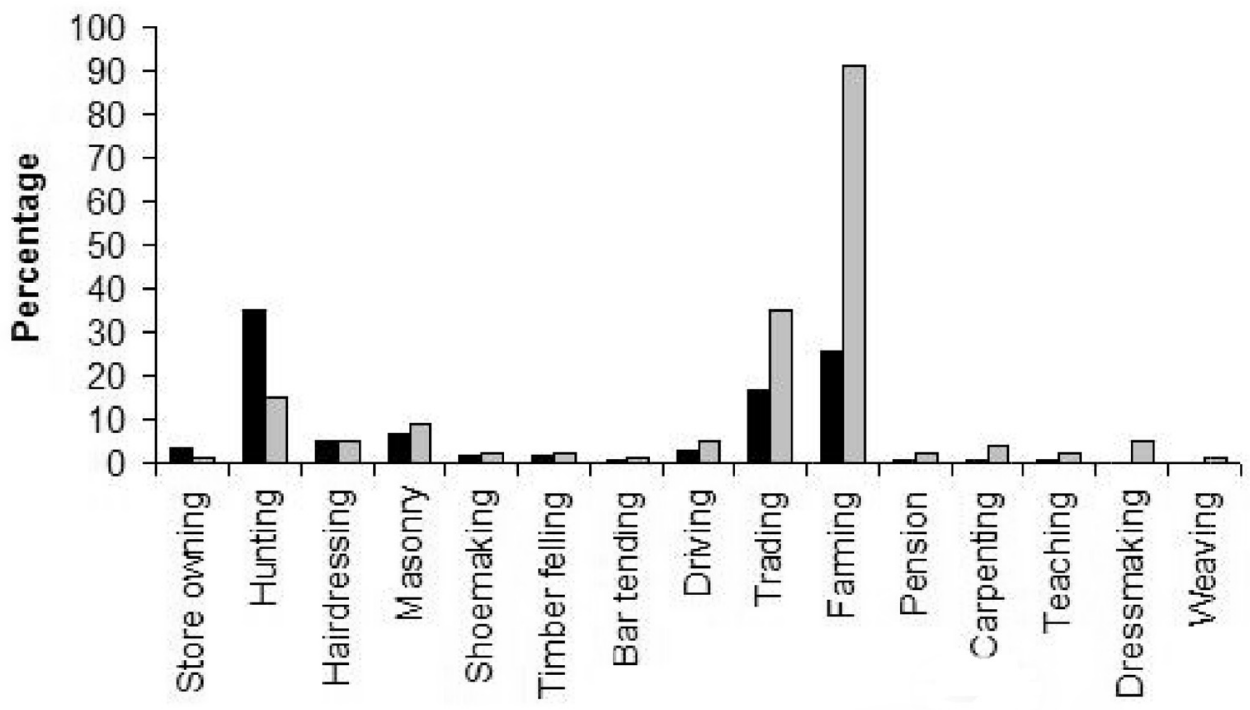

Per cent of total income $\square$ Per cent of hhs involved in activity

\section{Figure 2}

Proportion of total income derived from various economic activities in the study villages, and percentage of households involved in those activities 
A comparison between hunter and non-hunter household income (in the absence of income from hunting) indicates that non-hunting earnings from hunter households are significantly lower than in non-hunting households, for all villages with the exception of Nagode (Table 3). It is uncertain whether this is as a result of hunting activities taking time that would otherwise be spent on other income-generating activities, or because poorer families hunt to support their livelihoods. Farming activities generally provide considerably less income than hunting, although most hunters are also farmers.

Table 3

Annual income (million cedis, August 2002 values$^{1}$ ) excluding hunting for hunter and non-hunter hhs

\begin{tabular}{|l|c|c|c|c|}
\hline & Hunter & Nhunter & Average & P value $^{2}$ \\
\hline Nagode & 2.34 & 2.91 & 2.79 & 0.320 \\
\hline Pekyi No.1 & 1.77 & 3.93 & 3.75 & 0.006 \\
\hline Pakyi (Nkromma) & 1.59 & - & - & - \\
\hline Asotwe & 1.60 & 5.41 & 5.24 & 0.001 \\
\hline Atia & 1.96 & 4.34 & 3.79 & 0.003 \\
\hline Drobon & 2.02 & 3.17 & 2.97 & 0.044 \\
\hline
\end{tabular}

${ }^{1}$ Values from 2004 survey deflated to 2002 values using the Consumer Price Index (CPI).

In August 2002 one US dollar was worth approximately 8,000 Ghanaian cedis (\$)

${ }^{2}$ Student's t test comparing the means of the hunter and non-hunter households (Two-tail critical value)

\subsubsection{The direct costs of hunting}

There are at least eight direct cost components. Expenditure items include transportation to and from the market, equipment such as bags for carrying game, cutlasses, and material to build a trap. The major capital expenditure is rifles, valued at approximately 390,000 cedis in 2002 prices. The use of a carbide lamp for nocturnal hunting is also a costly purchase. At 340,000 cedis each, this is almost as expensive as a rifle. Together these items may constitute a quite an important barrier to entry for certain households. Traps on the other hand, are relatively cheap to make. A wire snare, for example, only costs 840 cedis each to produce. Very few hunters utilise the more expensive metal traps, which cost in the region of 25,000 cedis each.

\subsubsection{Contribution to Gross Domestic Product (GDP)}

Hunting contributed approximately US\$67 million to the economy of the Ashanti region in 2002, before the deduction of costs (Table 4), which is approximately four per cent of Ashanti GDP, after costs.

\section{Table 4}

Contribution of hunting to Ashanti Gross Domestic Product (GDP)

\begin{tabular}{|c|l|c|c|c|}
\hline Year & \multicolumn{1}{|c|}{ Study } & $\begin{array}{c}\text { Nominal value of } \\
\text { hunting - Ashanti } \\
\text { region (US\$ million) }\end{array}$ & $\begin{array}{c}\text { Real value of } \\
\text { hunting - Ashanti } \\
\text { region (US\$ million- } \\
\text { 2002 prices) }\end{array}$ & $\begin{array}{c}\text { Hunting profits } \\
\text { as percentage of } \\
\text { Ashanti GDP }\end{array}$ \\
\hline 1993 & Tutu et al. & 26.0 & 52.0 & 1.6 \\
\hline 2002 & Current survey & 67.1 & 67.1 & 3.9 \\
\hline
\end{tabular}




\subsection{Effect of distance to town on hunter behaviour}

\subsubsection{Hunting methods}

The hunters in the Ashanti region employ a wide range of hunting methods: shotguns, pistols, dogs, cutlasses and traps. The majority of hunters in the household survey use traps (59 per cent), although guns (41 per cent) are also frequently used, often in conjunction with traps. A possible reason for this is that, since most of the hunters are also farmers, they may be setting snares on their land to catch pests. The species that are caught with a trap are small species, particularly rodents. A much wider range of species are hunted using a rifle. The hunters targeted in the hunter survey have a slightly different set of characteristics compared with the household surveys. Approximately 69 per cent of these hunters use guns, compared with ten percent that use traps. In the correspondence analysis biplot (Figure 3), the two dimensions explain 81 per cent of the total variance (inertia).

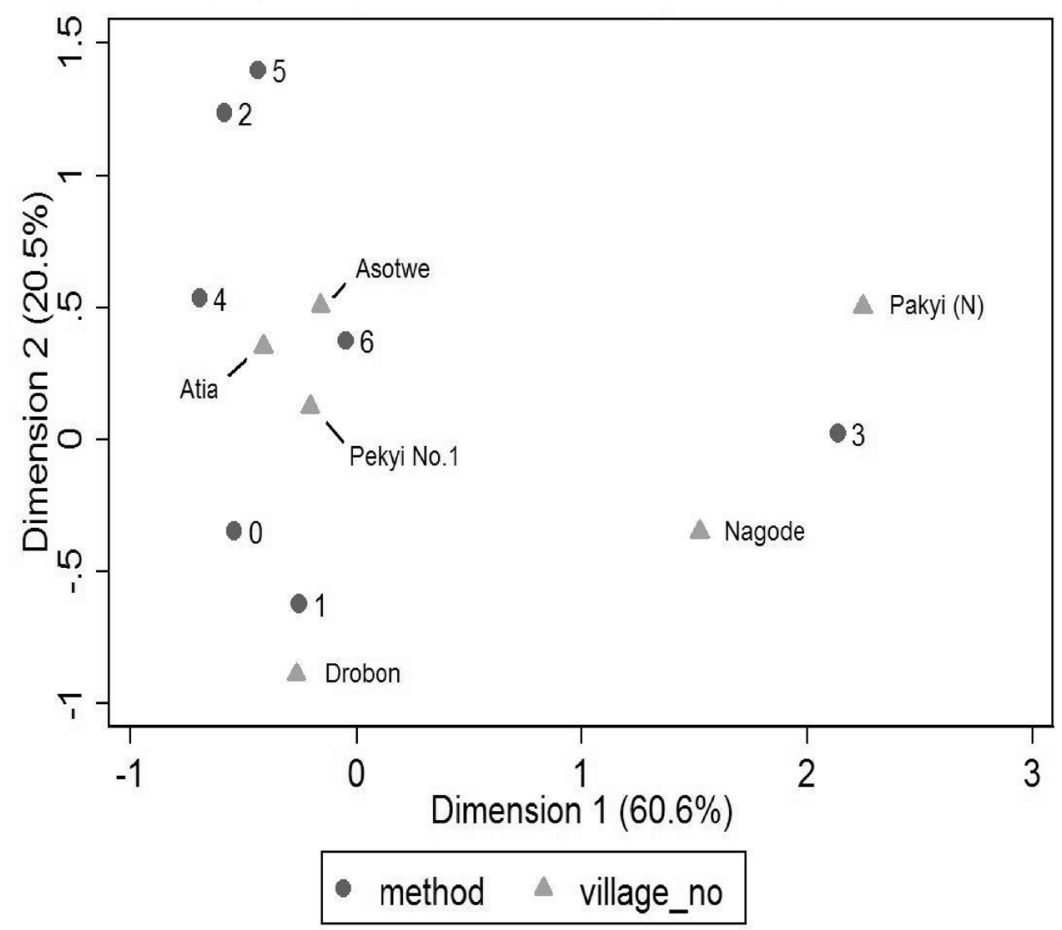

\section{Figure 3}

Correspondence analysis biplot for hunting methods used in each village: $0=$ none/missing $1=$ shotgun, $2=\operatorname{dog}, 3=\operatorname{trap}, 4=$ cutlass, $5=$ pistol, $6=$ combination

The results indicate that the range of techniques used appears to be related to distance to Kumasi. Villages closer to the Ashanti capital use a combination of techniques, as well as a wider range of techniques including cutlass, dogs and pistols. Villages further away from Kumasi use mainly shotguns (Drobon) or traps (Pakyi \& Nagode).

\subsubsection{Determinants of bushmeat sales}

Distance to the Ashanti capital is the major factor that determines whether a hunter sells in the village or sells in Kumasi (Table 5, deft $t_{\mathrm{V}}=$ 1.05, deft $_{\mathrm{K}}=1.12$ ). Hunters selling in Kumasi are also willing to substitute local consumption for sales, although this is not highly significant $(\mathrm{p}=$ 0.099 , deft $=1.30$ ). Those hunters that use traps are more likely to sell in the village $(\mathrm{p}=0.07$, $\operatorname{deft}=1.15)$. 


\section{Table 5}

Negative binomial regression for number of individuals sold in (1) the village and (2) Kumasi ${ }^{1}$

\begin{tabular}{|l|c|c|c|c|c|c|}
\hline \multirow{2}{*}{} & \multicolumn{3}{|c|}{ (1) Sales in Village } & \multicolumn{3}{c|}{ (2) Sales in Kumasi } \\
\cline { 2 - 7 } & beta/stat & s.e. & Sig. ${ }^{1}$ & beta/stat & s.e. & Sig. $^{{ }^{*}}$ \\
\hline Distance to Kumasi & 0.024 & $(0.007)$ & $* *$ & -0.026 & $(0.011)$ & $*$ \\
\hline Traps used & 0.988 & $(0.543)$ & $(*)$ & & & \\
\hline Consumed at home & & & & -1.131 & $(0.677)$ & $\left(^{*}\right)$ \\
\hline Model & 6.31 & & $* *$ & 3.39 & & $*$ \\
\hline Observations & 80 & & & 80 & & \\
\hline
\end{tabular}

Standard errors (s.e.) in parenthesis after each coefficient

${ }^{1}$ A positive sign on the "distance" coefficient represents a greater number of animals sold by a hunter in the location modelled (village or Kumasi) the further from Kumasi the village is; a positive sign on the "Traps used" coefficient represents a greater proportion of animals being sold in the location modelled if the hunter uses traps, and on the "consumption" coefficient a greater number of animals sold in the location modelled if hunters also consume bushmeat at home.

${ }^{2}$ Sig: $(*)$ significant at $\mathrm{P}<0.10 ;{ }^{*}$ significant at $\mathrm{P}<0.05 ;{ }^{* *}$ significant at $\mathrm{P}<0.01$

\subsection{Compliance with wildlife laws}

\subsubsection{Composition of the catch}

The most commonly hunted animal group are rodents and ungulates (Table 6). For the household survey, the majority of ungulates such as Maxwell's duiker (Cephalophus maxwelli) and bushbuck (Tragelaphus scriptus) are sold, while the majority of rodents such as giant rat (Cricetomys spp.) and grasscutter (Thryonomys swinderianus) are consumed at home.

\section{Table 6}

Proportion of respondents indicating that they hunted particular taxa, and proportion sold, given away or consumed in the study villages ${ }^{1}$

\begin{tabular}{|l|c|c|c|c|}
\hline Species group & \% Hunted & \% Consumed & \% Given away & \% Sold \\
\hline Rodents & 51 & 55 & 14 & 31 \\
\hline Ungulates & 37 & 28 & 32 & 40 \\
\hline Carnivore & 6 & 0 & 100 & 0 \\
\hline Birds & 2 & 0 & 0 & 0 \\
\hline Pangolin & 2 & 100 & 0 & 50 \\
\hline Primates & 1 & 50 & 0 & 50 \\
\hline Unknown & 1 & 50 & 0 & 0 \\
\hline
\end{tabular}

${ }^{1}$ Results on the species hunted are for the hunter survey and household survey combined. Proportions consumed, given away and sold are from the survey of hunters in the household survey (survey 1)

There are eight species reportedly hunted that are wholly protected under Ghana wildlife regulations. Of those, three are consumed at home (pangolin Manis spp., tree squirrel Sciuridae, and olive colobus Procolobus verus) and one is sold on the market (African civet Viverra civetta). The other protected species reportedly hunted for bushmeat include "the black and white monkey" (Colobus polykomos), the (two spotted) palm civet (Nandinia binotata), the forest Genet (Genetta tigrina maculata) and the yellow-backed duiker (Cephalophus silvicultor). 


\subsubsection{Relationship between hunting and farming activities}

For the household survey, both crops and closed season are significant determinants of hunting behaviour, suggesting that there is some compliance with wildlife regulations, at least reportedly (Table 7). The closed season variable is correlated with months when crops are harvested $\left(\mathrm{R}^{2}=0.62, \beta_{\text {CLOSED }}=-1510, \mathrm{P}=0.002\right)$ making it hard to disentangle laws from other determinants of behaviour. Not surprisingly, therefore, the combined model where both crops and closed season are regressed together is not highly significant, although the effect of the closed season dominates $(d e f t=0.45)$. In the hunter survey, on the other hand, hunting in the closed season is significant and negative $(\mathrm{p}<0.05$, deft $=1.09)$ indicating that hunters hunt more in those months. Crops are also significant and positive $($ deft $=1.07)$ when regressed individually, and in the combined model, crops are significant $(d e f t=0.54)$ and the closed season is not significant $(d e f t=0.58)$.

\section{Table 7}

Logistic regression for the months in which hunters hunt (1) or not (0), regressed against whether the month is one in which crops are predominately harvested and whether the month is in the closed or open season, for two datasets (household survey and hunter survey).

\begin{tabular}{|c|c|c|c|c|c|c|c|c|c|}
\hline \multirow[b]{2}{*}{ Model $^{1}$} & \multicolumn{9}{|c|}{ Household survey } \\
\hline & (1) & s.e. & Sig $^{2}$ & (2) & s.e. & Sig $^{2}$ & (3) & s.e. & Sig $^{2}$ \\
\hline Crops & -0.0002 & $(0.0003)$ & & -0.0006 & $(0.0003)$ & $(*)$ & & & \\
\hline Closed & 0.9307 & $(0.3273)$ & $* *$ & & & & 1.299 & $(0.5389)$ & $(*)$ \\
\hline Model & 4.06 & & $(*)$ & 4.07 & & $(*)$ & 5.81 & & $*$ \\
\hline \multirow[t]{2}{*}{ Observations } & 288 & & & 288 & & & 288 & & \\
\hline & \multicolumn{9}{|c|}{ Hunter survey } \\
\hline Model' & (1) & s.e. & Sig $^{2}$ & (2) & s.e. & Sig $^{2}$ & (3) & s.e. & $\mathrm{Sig}^{2}$ \\
\hline Crops & 0.0003 & $(0.0001)$ & $* *$ & 0.0004 & $(0.0001)$ & $* *$ & & & \\
\hline Closed & -0.0835 & $(0.1917)$ & & & & & -0.5678 & $(0.2365)$ & $*$ \\
\hline Model & 5.99 & & $* *$ & 8.71 & & $* *$ & 5.76 & & $*$ \\
\hline Observations & 768 & & & 768 & & & 768 & & \\
\hline
\end{tabular}

Standard errors (s.e.) in parenthesis after each coefficient

${ }^{1}$ Model $1=$ crops + closed season, Model $2=$ crops alone, Model $3=$ closed season alone. A positive coefficient on the "Crops" variable means that hunters hunt more in months when crops are harvested; a negative coefficient on the "Closed" variable means that hunters hunt more in months which are in the official closed season.

${ }^{2}$ Sig: $\left(^{*}\right)$ significant at $\mathrm{P}<0.10$; ${ }^{*}$ significant at $\mathrm{P}<0.05$; ** significant at $\mathrm{P}<0.01$ level

\section{4}

\section{Discussion}

While the contribution of bushmeat to the protein requirements of Ghanaians has declined in recent years (Bowen-Jones et al., 2003), bushmeat remains an important commodity in rural livelihoods. In 2002, hunting represented approximately four percent of Ashanti Gross
Domestic Product (GDP), which is the same ratio as the ratio of hunters in the survey set. Most of these earnings do not form part of the standard national accounts data for Ghana. Furthermore, this value has not declined over time, as one might have expected. Factors that might influence the value of bushmeat include the changes in the dollar-denominated price of bushmeat, and population growth resulting 
in increased demand for bushmeat as well as changes in the hunter population.

Our results indicate that it is mainly poorer households that engage in hunting. Hunter households earn significantly less from other activities than non-hunter households. It is not clear whether the lower income is a reason for hunting, or a result of hunting activities borrowing time from other economic pursuits. Notwithstanding this, bushmeat plays a valuable part in the local diet of rural consumers. Even in the hunter survey, which has a higher proportion of professional hunters, 35 per cent of bushmeat is consumed locally in the study villages.

Distance to the main bushmeat markets in Kumasi plays an important role in determining whether bushmeat is sold in the city or used locally. This is an interesting finding given that a larger proportion of overall supply to the Atwemonom market in Kumasi comes from the outer portion of the catchment (Crookes et al., 2005), and suggests that a large portion of the supply does not reach the city markets. Distance to Kumasi is also an important determinant of which hunting method is used. For example, a combination of techniques is used in villages close to Kumasi. This could be a consequence of depletion close to the Ashanti capital, requiring a broader range of methods to hunt wild animals.

The majority ( 88 per cent) of bushmeat hunted are rodents and ungulates. A high proportion of the rodents are consumed at home while the ungulates, notably Maxwell's duiker and bushbuck, are sold. Furthermore, the hunters reported hunting a number of protected species, some of which are consumed in the villages and some sold on the market. The limited success of Ghana's existing policy of species restrictions has also been observed in market studies (Ntiamoa-Baidu, 1998; Crookes \& MilnerGulland, 2006).

A number of studies have reported that hunting activity increases during lean periods and decreases during periods of abundance (Dei, 1989,1991; de Merode et al., 2004). We find some evidence for this amongst hunters in the household survey, although the relationship is complex and also relates to compliance with the legal closed season. Professional hunters in the hunter survey, on the other hand, actually hunt more during the agricultural peak period and the closed season. Possibly this is due to less competition for wild resources during those months, and also to meet market demand during months when farmer hunters are otherwise occupied.

We have characterised the role of hunting in livelihoods for an area of Ghana, to provide further empirical evidence which contributes to effective policy-making for the conservation of bushmeat species.

\section{Endnotes}

1 Deft measures the deviation of the standard error of the survey from the standard error based on simple random sampling (SRS). A value of, for example 1.6, means that the standard errors of the survey are 60 percent larger than they would have been under SRS. Although there are no established intervals within which deft should fall, values under 1.75 are fairly common in well designed studies (see Shackman, 2001 for a literature review).

2 See footnote to Table 3 for applicable exchange rates.

\section{Acknowledgements}

We would like to thank Dr William Oduro of Kwame Nkrumah University of Science and technology, Kumasi, as well as Okyeame Ampadu-Agyei of Conservation International West Africa for useful assistance while the lead author was in Ghana. Funding from Conservation International is gratefully acknowledged.

\section{References}

1 ASIBEY, E.O.A. (1987) "Wildlife issues in sub-Saharan Africa", Paper presented at the International Symposium and Conference: Wildlife Management in Sub-Saharan Africa, 6-12 October. Sponsored by FAO and the International Council for Game and Wildlife Conservation, Harare, Zimbabwe, pp. 32-50.

2 ASIBEY, E.O.A. \& CHILD, G.S. (1990) "Wildlife management for rural development in sub-Saharan Africa”. Unasylva, 41(161):3-10. 
3 BOWEN-JONES E.; BROWN, D. \& ROBINSON, E.J.Z. (2003) "Economic commodity or environmental crisis? An interdisciplinary approach to analysing the bushmeat trade in central and west Africa”, Area 35(4): 390-402.

4 BRASHARES, J.S.; ARCESE, P.; SAM, M.K.; COPPOLILLO, P.B.; SINCLAIR, A.R.E. \& BALMFORD, A. (2004) "Bushmeat hunting, wildlife declines, and fish supply in West Africa", Science 306: 1180-1183.

5 CASPARY, H-U. (1999) Wildlife Utilization in Cote d'Ivoire and West Africa-Potentials and Constraints for Development Cooperation, Eschborn, Germany: Tropical ecology support program.

6 COWLISHAW, G.; MENDELSON, S. \& ROWCLIFFE, J.M. (2005) "Evidence for postdepletion sustainability in a mature bushmeat market", Journal of Applied Ecology, 42: 460-468.

7 CROOKES, D.J.; ANKUDEY, N. \& MILNERGULLAND, E.J. (2005) "What can long term market data tell us? A case study of Atwemonom bushmeat market, Ghana", Environmental Conservation: 32(4): 333-339.

8 CROOKES, D.J. \& MILNER-GULLAND, E.J. (2006) "Wildlife and economic policies affecting the bushmeat trade: A framework for analysis", South African Journal of Wildlife Research, 36(2): 159-165.

9 DAMANIA, R.; MILNER-GULLAND, E.J. \& CROOKES, D.J. (2005) "A bioeconomic analysis of bushmeat hunting", Proceedings of the Royal Society B. 272: 259-266.

10 DE MERODE, E.; HOMEWOOD, K. \& COWLISHAW, G. (2004) "The value of bushmeat and other wild foods to rural households living in extreme poverty in the eastern Democratic Republic of Congo", Biological Conservation 118: 573-581.

11 DEI, G.S. (1989) "Hunting and gathering in a Ghanaian rain forest community", Ecology of Food and Nutrition, 22: 225-243.

12 DEI, G.S. (1991) "The dietary habits of a Ghanaian Farming community", Ecology of Food and Nutrition, 25: 29-49.

13 GHANA STATISTICAL SERVICE (2000) Ghana Living Standards Survey. Report of the Fourth Round (GLSS 1998/99) Ghana Statistical Service: Accra.

14 GHANA STATISTICAL SERVICE (2002) 2000 Population and Housing Census. Summary Report of Final Results, Ghana Statistical Service: Accra.

15 GREENACRE, M.J. (1984) Theory and Applications of Correspondence Analysis, Academic Press: London.
16 GREENACRE, M.J. (2006) "Tying up the loose ends in simple correspondence analysis", Working Report 940, Department of Economics and Business, Universitat Pompeu Fabra.

17 HILL, M.O. (1974) "Correspondence analysis: A neglected multivariate method", Applied Statistics, 23(3): 340-354.

18 HOFMANN, T., ELLENBERG, H. \& ROTH H. (1999) Bushmeat: A Natural Resource of the Moist Forest Regions of West Africa with Particular Consideration of Two Duiker Species in Côte D'ivoire and Ghana, TöB Publication number TöB F-V/7e. GTZ: Eschborn, Germany.

19 KISH, L. (1982) "Design effect", In: S. Kotz and N.L. Johnson (eds.) Encyclopaedia of Statistical Sciences: Vol.2, Wiley: New York.

20 KISH, L. (1995) "Methods for design effects", Journal of Official Statistics, 11(1): 55-77.

21 KORANG, T. (1986) "Impact of forest management on the rural population: A case-study of the Subri Project”, Kumasi, Ghana, Institute of Renewable Natural Resources, University of Science and Technology. (Unpublished thesis.)

22 LIVESTOCK AND WILDLIFE ADVISORY GROUP (LWAG) (2002) Wildlife and Poverty Study, Department for International Development: London.

23 MILNER-GULLAND E.J. \& CLAYTON L.M. (2002) "The trade in wild pigs in North Sulawesi, Indonesia”, Ecological Economics, 42: 165-183.

24 NTIAMOA-BAIDU, Y. (1987) "West African wildlife: A resource in jeopardy", Unasylva, 156, 39(2): 27-35.

25 NTIAMOA-BAIDU, Y. (1998) Wildlife Development Plan. Volume 6- Sustainable Harvesting, Production and Use of Bushmeat, Wildlife Department: Accra, Ghana.

26 ORGANISATION FOR ECONOMIC COOPERATION \& DEVELOPMENT (OECD) (2000) System of National Accounts, 1993- Glossary, OECD publications: Paris.

27 OWUSU, E.H.; NTIAMOA-BAIDU Y. \& EKPE E.K. (2006) "The dependence of local people on bushmeat in the Afadjato and Agumatsa Conservation Area, Ghana", Nature \& Faune, 21(1): 33-44.

28 SHACKMAN, G. (2001) "Sample size and design effect", Presented at Albany Chapter of American Statistical Association, March 24, 2001.

29 STATACORP (2005) Stata Statistical Software: Release 9. College Station, TX: StataCorp LP.

30 TUTU, K.; NTIAMOA-BAIDU, Y. \& ASUMING-BREMPONG, S. (1993) "The 
economics of living with wildlife: Ghana”, Report prepared for the World Bank: African Technical division.

31 WILKIE, D.S.; STARKEY, M.; ABERNETHY, K.; EFFA NSAME, E.; TELFER, P., \& GODOY, R. (2005) "Role of prices and wealth in consumer demand for bushmeat in Gabon, Central Africa", Conservation Biology 19 (1): 1-7.

32 WUVER, A.M. \& ATTUQUAYEFIO, D.K. (2006) "The impact of human activities on biodiversity conservation in a coastal wetland in Ghana”, West Africa Journal of Applied Ecology, 9. 